\author{
Юлія Олександрівна Грібінєнко \\ https://orcid.org/0000-0003-4891-5157 \\ кандидат мистецтвознавства, доцент кафедри \\ історії музики та музичної етнографії \\ Одеської національної музичної \\ академії ім. А. В. Нежданової \\ j.a.g@ukr.net

\section{СЕМАНТИКО-КОМПОЗИЦЙНІ ФУНКЦІЇ ІНСТРУМЕНТАЛЬНОГО ТЕМБРУ У ТВОРЧОСТІ Г. УСТВОЛЬСЬКОЇ (НА ПРИКЛАДІ КОМПОЗИЦІЇ № 1)}

\begin{abstract}
Метою роботи стає виявлення специфіки індивідуально-авторського втілення можливостей інструментального тембру в творчості Г. Уствольської, а також розкриття тембрової своєрідності творів композиторки на прикладі Композиції № 1. Методологічною основою дослідження є системно-аналітичний та жанрово-стильовий підходи. Залучаються текстологічний та виконавський стилістичний аналізи. Наукова новизна. Представлена в статті сторона інструментального почерку композиторки на сьогоднішній день залишається за рамками авторитетних досліджень, присвячених особливостям стилю Г. Уствольської. Цей дослідницький ракурс допомагає виявити якісно нову, відмінну від інших, сферу образності, що сформувалася в творчості композиторки; розширює уявлення про природу музики Г. Уствольської за рахунок визначення тембрових якостей ї̈ творів. Тембровий аспект творів композиторки проявляє себе також в незмінній перевазі певних інструментальних тембрів, серед яких вагому роль відіграє тембр туби, що отримує особливе структурно-семантичне значення в розгортанні драматургї̈ творів Г. Уствольської. Висновки. Авторське трактування тембрів інструментів в Композиції № 1 формується в контексті концентрованого композиторського мислення Г. Уствольської, що не допускає навіть думки не те що про зайві, але й просто про додаткові деталі. Така спрямованість визначає важливе значення особливостей тематизму, ритміки, будови вертикалі і динаміки в вибудовуванні образів інструментальної партитури.
\end{abstract}

Ключові слова: інструментальний тембр, темброва драматургія, інструментальна музика, Композиція, тембр туби. 
Grybynenko Julia, Ph.D. in the History of Art, assistant professor of the department of music history and musical ethnography of Odessa National A. V. Nezhdanova Academy of Music

Semantico-compositional functions of the instrumental timbre in the work of G. Ustvolskaya (on the example of Composition No. 1)

The purpose of the work is to identify the specificity of the individual and author's implementation of the instrumental timbre in G. Ustvolskaya's work, as well as the timbre peculiarity of the composer's works on the example of Composition No. 1. The methodology of the research basis of this study is the system-analytical and genre-style approaches. Textual and performing stylistic analyzes are attracted. Scientific novelty. The presented in the article side of the composer's handwriting of the composer today remains beyond authoritative studies devoted to the peculiarities of G. Ustvolskaya's style. This research perspective helps to reveal a qualitatively new sphere of imagery, different from the others, formed in the composer's work; expands the idea of the nature of music $G$. Ustvolskaya by determining the timbre qualities of her works. The timbre side of the composer's works also manifests itself in the author's invariable preference for certain instrumental timbres, among which the timbre of trumpet plays a significant role, which acquires a special structural and semantic significance in the development of the playwriting of G. Ustvolskaya's works. Conclusions. The author's interpretation of the timbres of instruments in Composition No. 1 is formed in the context of Ustvolskaya's concentrated compositional thinking, which does not even allow thought to be anything but superfluous, but simply about additional details. This orientation determines the importance of the features of thematic, rhythmic, vertical structure and dynamics in the alignment of the images of instrumental score.

Keywords: instrumental timbre, timbre dramaturgy, instrumental music, Composition, timbre of trumpet.

Грибиненко Юлия Александровна, кандидат искусствоведения, доцент кафедры истории музыки и музыкальной этнографии Одесской национальной музыкальной академии им. А. В Неждановой

Семантико-композиционые функции инструментального тембра в твориестве Г. Уствольской (на примере Композиции № 1)

Целью работы становится выявление специфики индивидуальноавторского претворения возможностей инструментального тембра в творчестве Г. Уствольской, а также раскрытие тембрового своеобразия произведений композитора на примере Композиции № 1. Методологической основой исследования являются системно-аналитический и жанрово-стилевой подходы. Привлекаются текстологический и исполнительский стилистический анализы. Научная новизна. Представленная в статье сторона инструментального почерка композитора на сегодняшний день остается за рамками авторитетных исследований, посвященных особенностям стиля $Г$. Уствольской. Этот исследова- 
тельский ракурс помогает выявить качественно новую, отличную от других, сферу образности, сформировавшуюся в творчестве композитора; расширяет представление о природе музыки Г. Уствольской за счет определения тембровых качеств ее произведений. Тембровая сторона произведений композитора проявляет себя также в неизменном предпочтении автором определенных инструментальных тембров, среди которых весомую роль играет тембр тубы, приобретающий особое структурно-семантическое значение в развертывании драматургии произведений Г. Уствольской. Выводы. Авторская трактовка тембров инструментов в Композиции № 1 формируется в контексте концентрированного композиторского мышления Уствольской, не допускающего даже мысли не то что о лишних, но просто о дополнительных деталях. Такая направленность определяет важное значение особенностей тематизма, ритмики, строения вертикали и динамики в выстраивании образов инструментальной партитуры.

Ключевые слова: инструментальный тембр, тембровая драматургия, инструментальная музыка, Композиция, тембр тубы.

Актуальність дослідження. Своєрідність тембрового мислення Галини Уствольської проявляється в музиці всіх жанрів, до яких вона звертається. Крайні диспропорції, дисбаланс інструментарію поєднуються в творах композиторки з принципами тембрової персоніфікації, обмеженість складів з багатством тембрової палітри, нова функціональність інструментарію зі зверненням до традиційних тембрів. Всі перераховані фактори вказують на підвищення ролі тембру в творчості Галини Уствольської як емоційно-виразного та композиційно-структурного елемента, на збільшення його питомої ваги в загальній фабулі, архітектоніці їі творів. Однак інтерес до цієї сторони інструментального почерку композиторки на сьогоднішній день залишається за рамками авторитетних досліджень, присвячених розкриттю особливостей стилю Г. Уствольської. Цей дослідницький ракурс допомагає виявити якісно нову, відмінну від інших, сферу образності, що сформувалася в творчості композиторки; розширює уявлення про природу музики Г. Уствольської за рахунок визначення тембрових якостей іiі творів.

Метою статті стає виявлення специфіки індивідуально-авторського втілення можливостей інструментального тембру в творчості Г. Уствольської, а також розкриття тембрової своєрідності творів композиторки на прикладі Композиції № 1 «Dona nobis pacem».

Виклад основного матеріалу. В інструментальних композиціях Г. Уствольської слухове сприйняття спрямоване на окремий звук, в 
якому складна взаємодія параметрів - висотних, ладових, гармонійних, метроритмічних, динамічних, артикуляційних та тембрових організовує енергію особливого напруження всієї музичної тканини. Звукова матерія цієї музики створює поле найвищого емоційного градуса. Її не можна тільки прослухати, її необхідно прожити - вона обпікає експресією та болем, який ховається під тонким панциром «зовнішньої суворості, замкнутості, навмисної неупередженості» [1, 101]. Тому саме іманентно музичні фактори відіграють найважливішу роль в емоційно-образному втіленні композиторських висловлювань.

Звук в творах Г. Уствольської індивідуалізований за допомогою інструментального тембру, який персоніфікується, оскільки наділений тембровою характеристичністю. У творах композиторки тембри музичних інструментів уподібнюються звучанню людського голосу. Він же ототожнюється автором 3 «голосом» трагічного героя. Мовний прообраз в інструментальних п'єсах переломлюється по-різному. В одному випадку в мелодиці соло інструментів витримана вокальна теситура звучання, в іншому - парадоксальним чином інструментальний виконавський діапазон не обмежений, а часто й «граничний».

На пріоритет останньої якості у всій інструментальній творчості Г. Уствольської звертає увагу Тетяна Чередниченко. Про велику роль фактора «незручності» при виконанні творів композиторки говорить те, що виконавці грають у важких регістрах, «які найбільше не рекомендують в інструкціях з оркестровки». «Кожен голос повторює свій малюнок на межі можливостей, у висотній і / або гучнісній зоні, яка чи не фізіологічно резонує межею людського звершення» [7, 362].

На фактор фізичного дискомфорту, присутній в творах Г. Уствольської, також звертає увагу А. Гнатенко. У своєму дослідженні фортепіанної творчості композиторки музикознавець наводить приклади авторських ремарок, виконання яких викликає больові відчуття у піаніста при грі, наприклад, П'ятої або Шостої сонати [2]. На наш погляд, такі ремарки цінні і необхідні для виконавців, тому що допомагають розставити смислові акценти в творах, непростих для гри в метрорітмичному аспекті, а також для розуміння внутрішньої спрямованості.

Слід зазначити, що внутрішній стан трагічного героя творів Уствольської визначає взаємозв'язок з авторським сприйняттям навколишнього світу. Звідси походить особливий особистісно-суб'єктивний, сповідальний тон музичного вираження. Твори Г. Уствольської справляють враження загадки - вони «зашифровані», але уважне вслуховування виявляє в них «оголене почуття, чи не сповідь» 
$[3,16]$; «Немає нічого значнішого та грандіознішого самозабутнього, ревного звернення самотньої людини до Бога» $[3,14]$. Сповідальність визначає «концепційну лінію» творчості Уствольської і стає однією 3 найважливіших тем їі музичної філософії.

Інструментальний склад Композиції № 1 «Dona nobis pacem» досить оригінальний. Цей твір написано для трьох інструментів флейти пікколо, туби і фортепіано. Роль кожного інструмента в творі незвичайна, як і загальний інструментальний склад. «Ультратембрів» в Композиції немає, кожен інструмент виступає як соліст. У драматургії твору виразно намічається розшарування на два плани-голоси, доручені партіям туби і флейти пікколо. Об'єднуючою ланкою стає тембр фортепіано, представлений у вигляді ударно-дзвонної звучності. Партія цього інструмента насичена різкими кластерами, секундовими гронами, які кинуті недбало, відчайдушно, а в високому регістрі нагадують металевий дзвін.

Потужний звук туби в контроктаві та свистячий звук флейти пікколо грають в Композиції роль протилежних планів-полюсів. Вибрані тембри часто «оркестрові» за силою звучності, що їх врівноважує. Серед нечисленних музичних інструментів композиції провідну мелодійну лінію композиторка доручає тубі. Саме іiі соло відкриває звучання Композиції. Хоча при цьому в творі кожен інструмент має право називатися солюющим. Тембри зливаються, незважаючи на те, що на перший погляд важко повірити в їх сумісність. Інструменти звучать в єдиному хороводі, стрімкому потоці, змальовуючи загальний напружений характер твору.

Спроби музикознавчих осмислень Композиції № 1 не привели дослідників творчості Уствольської до єдиної думки. Так, наприклад, Б. Кац виявляє в цьому творі відображення концепції, властивої для творчості Д. Шостаковича, яка може бути втілена за наступною схемою: перша частина - натиск, розпад, катастрофа, друга частина протистояння, протест та третя частина - заціпеніння, благання [3]. Всі перераховані стадії рельєфно виражені в Восьмій симфонії Д. Шостаковича. Інші музикознавці, серед них О. Гладкова та А. Гнатенко, розглядають Композицію як звернення до внутрішнього стану особистості, до показу шляху здобуття людиною внутрішньої чистоти. Це образний розвиток будується на діалогічному протистоянні сфер - спокою та мани, руйнування та тиші [1; 2].

Особливою властивістю, що показує, з одного боку, глибину тембрових якостей обраних в Композиції інструментів, з іншого, іманент- 
ною складовою музичної мови Уствольської стає гранична експресія. Вона виникає в результаті постійного прагнення до протиставлення динаміки, причому кожен з нюансів доведений до межі (часто вживається композиторкою ремарка espressivissimo, що також підтверджує високе емоційне напруження творів). Всередині твору динаміка коливається від pppp до fffff в різних градаціях. Ось, наприклад, загальний динамічний план першої частини Композиції:

\section{ff fff $p$ fff ffff $\boldsymbol{p}$ fff fffffffff $\boldsymbol{p}$ fff fff ffff $\boldsymbol{p} p \boldsymbol{p} \boldsymbol{p} \boldsymbol{p p p}$}

Подібні динамічні перепади сприяють розширенню простору звукосвіту Г. Уствольської. Композиторка зіштовхує крайності динаміки, також як і крайності регістрів і тембрів. Авторські ремарки в партитурах дають нерідко градації гучності (від п’яти форте до п’яти піано), але для Г. Уствольської важлива не граничність динаміки сама по собі, а прагнення до перспективи, до істинної далі, до «Вищого в вічності»: використання позамежної динаміки є в певному роді символом волі, що проводить за кордони будь-яких обмежень.

Композиція трьохчастинна. Однак завдяки наявності наскрізної лейтінтонації музичний матеріал всіх частин твору сприймається як продовження одне одного. Крім того, друга й третя частини Композиції за задумом композиторки повинні виконуватися аttaca. Таким чином, в побудові форми Композиції спостерігається явне прагнення до одночастинності.

Вся перша частина чітко ділиться на сім розділів, драматургія і структура яких будується на варіюванні провідної інтонації основної теми. Кожен з розділів контрастний відносно попереднього темпово і / або відрізняється тембровим наповненням.

Перший розділ починається з потужного звучання соло туби. Основна тема викладається за допомогою різкого акцентування кожної ноти. Цікаво, що цей штрих проникає в партії всіх учасників ансамблю та знімається тільки в третьому розділі, який примирює обидві сторони. До одинокого гарчання інструменту в контроктаві незабаром приєднуються різкі кластери фортепіано в високому регістрі. Кластерні звучання не тільки служать величезній драматургічній напрузі (образам плачу, страждання, тому що грунтуються на гронах секундових інтонацій в гармонічному звучанні), але й створюють відчуття ритуального характеру музикування.

Тема-зерно будується на секундових ходах, які не поспішаючи розширюють свій діапазон до меж кварти. Для неї характерні пощаблеві 
звукові послідовності прямого, найчастіше висхідного або хвилеподібного малюнку. У подібному русі перевага віддається секундовим інтонаціям, які в процесі розгортання вичленовуються та звучать або як ламентозні ходи, або як інтонації протесту, крику (в експресіоністському трактуванні), або як екстатичні, монотонно повторювані інтонації «болісно-блаженної несамовитості». Зауважимо, що тяжіння до тематизму подібного формату, заснованого на коротких поспівках, імпульсах властиво для усієї творчості Г. Уствольської.

Власне мелодійний зміст теми оформлено в гранично лаконічні (часто на рівні мотиву) мелодико-інтонаційні «стрижні». Важливу роль у створенні тематичної характерності грає в композиції тембросонорний фактор. Поряд з традиційними способами розвитку (вичленування з тематичного осередку елемента та його розвиток; ритмічна зміна мотивів, поліфонічне перетворення (ракохід, обвернення), варіювання і т. д.), Г. Уствольська створює своє коло прийомів, яке включає реєстрово-темброві перефарбування та зміну артикуляції, що стали важливою та невід'ємною частиною контрапунктичних перестановок, оскільки за кожним тематичним елементом в експозиції закріплений певний тип артикуляції. Такий тематизм, в якому першорядні не тільки мелос, але й тембр, й артикуляція є особливою «інтонацію, що організована на основі рівнофункціональної (в сенсі спрямованості на створення ефекту тематичної характерності) взаємодії різних виразних чинників» [5, 52]. Використання композиторкою подібного тематизму в своїй творчості ще раз підтверджує думку про те, що твори Г. Уствольської мають глибоку смислову ємність, високий рівень інформативності та змістовності. Саме такий тематизм і дозволяє досягти композиторці повного втілення цих стильових рис.

Звуки туби, які експонують головну тему, наділені особливою глибиною та щільністю звучання, чого і вимагає автор від виконавця. Уствольська просить тубіста грати кожну ноту осмислено, глибоко, так, як якщо б на неї падав вимовленний з усією вагомістю склад глибоко значимого слова. У партитурі це прохання композиторки знаходить вираз в акцентуванні, артикуляційному підкресленні кожної ноти в партіях туби та флейти пікколо, кожної ноти або співзвуччя у фортепіано прийомами sforzando i / або marcato. Цей виконавський прийом вказує на значущість, глибоке смислове наповнення кожного звуку основної теми і кожного звуку твору, з одного боку, та формує високий градус напруги в партитурі Композиції, з іншого. 
Для мідних духових інструментів marcato - найбільш природний та широко вживаний штрих. Слід зазначити, що термін marcato в духовій практиці дуже часто застосовується як синонім терміну «акцент», оскільки в побуті найхарактернішою ознакою цього штриха вважається саме акцентованість. На думку О. Харитонова, ці поняття необхідно чітко розділити. Термін «акцент» має бути пов'язаний в першу чергу зі сферою динаміки та означати динамічне виділення всього звуку, або виділення початку звуку з активним динамічним спадом в «стаціонарній» частині. Термін marcato має означати конкретний штрих, тобто якісно визначене комплексне явище, в якому акцентованість - лише один з компонентів звуковидобування [4].

Акцентованість - явище саме по собі не унікальне, притаманне не тільки штриху marcato, а в цілому властиве членороздільному, дискретному типу звуковидобування. Це повною мірою пояснює велику кількість акцентованих звуків в музичній тканині творів Утвольської, які стають іманентною складовою ії стилю.

Гучнісні акценти, які супроводжують тему, завжди зрозумілі, відкриті, очевидні. Характерна риса цього явища - «рупорність», що підсилює до крику важливі смислові точки твору. Уствольська, як автор, що ставиться до явищ навколишнього мікро- та макросвіту надзвичайно серйозно, в своїй творчості - спілкуючись з виконавцями, слухачами - «кричить», волає.

Слід звернути увагу ще на одну деталь, marcato - штрих, який застосовується в досить обмежених темпових рамках духової практики, - від повільного до помірного. Процес згасання вимагає часу для того, щоб встигнути бути відтвореним та сприйнятим. Але Уствольська ставить перед тубістом завдання виконання швидких звукових послідовностей, які призводять циклічний режим роботи дихальних м'язів (посилення і спади їх активності на кожному звуці) до швидкої втоми, а значить, вимагають додаткових зусиль від виконавця. В якійсь мірі композиторка змушує виконавця «вистраждати» текст Композиції, який колись нелегкою працею дістався і їй. Додамо, що про «вистражданність» своїх творів Уствольська говорила неодноразово. Так, якщо їй щось однозначно не подобалося в виконанні іiі музики, і вона була проти цього, композиторка категорично наголошувала: «Не для того страждала».

Крім того, важливого значення в артикуляційному плані набуває прийом glissando, що залишається прерогативою партій туби та флейти пікколо протягом усієї Композиції. Уствольська трактує цей ви- 
конавський прийом як значний у вибудовуванні образного каркаса основної теми та як прийом, що руйнує рівномірну темперацію музичної мови й «звільняє» іiї музику, шо дозволяє прямувати за кордони обмежень.

Тема, викладена у туби (зауважимо, що і в цілому партія цього інструмента), звучить переважно на $\boldsymbol{f}$, в різноманітніших градаціях. Ці динамічні відтінки додають густому тембру інструмента металевий блиск. Звук ніби не вміщується в інструменті, і туба починає дрібно тремтіти по всій своїй довжині. Цей специфічний для туби нюанс був помічений не тільки Г. Уствольською та досить широко застосовувався іншими композиторами. Таку тубу можна почути, наприклад, в балеті С. Прокоф’єва «Ромео і Джульєтта»

Початкова тема Композиції незмінно прозвучить двічі: як вступ та повноцінне проведення в партіях флейти пікколо й фортепіано. Надалі, розвиваючи тему, композиторка доручає ії фортепіано, в партії якого вона (тема) піддається різним перетворенням (ми почуємо іiї в обігу). На тлі триваючого варіаційного розвитку елементів основної мелодійної побудови почне формуватися друга тема, витоки якої лежать в одному з мотивів першої. 3 одного з мотивів першої тут вичленуються окремі мотиви другої теми та по черзі звучать у всіх голосах: від флейти пікколо до фортепіано, а потім до туби. Б. Кац порівнює ці переклички з поліфонічним прийомом проведення другої теми в подвійній фузі [3].

У третьому розділі починається розробка двох основних тем. У напруженому, експресивному звучанні окремі інтонації стикаються, перегукуються в партіях різних інструментів, темброво перевдягаються. Музична тканина то ущільнюється за допомогою неймовірно потужних хроматичних кластерів, то постає в виразному одноголоссі. У стрімкому хороводі, сплітаючись, кружляють дві теми, зливаючись та стикаючись, відкрито конфліктуючи. Гранично гучна динаміка кожен інструмент повторює свій малюнок на межі своїх тесітурних можливостей; таким загальним хаосом композиторка наповнює четвертий і п’ятий розділи твору.

Шостий розділ являє собою репризу, в якій повертається початковий темп, інтонації оспівування у флейти та кластери фортепіано, але на відміну від експозиції, де основна тема була у туби, тут вона проводиться у фортепіано в нижньому регістрі, що в тембровому відношенні згладжено і звучить не так різко й напружено, як у це було у виконанні туби. Завершується перша частина кодою, яка побудована 
на інтонації з головної теми: в басі висхідні секунди, які перегукуються з тими, шо сходять пощаблево ходами в іншому голосі.

Друга частина Композиції ніби вривається в тишу різкими хроматичними кластерами, знайомими за музичним матеріалом першої. Тут композиторка точно та детально описує виконавські прийоми звуковидобування кластерів, які представлені дуже різноманітно. Драматургія другої частини будується на протистоянні речитативних інтонацій у туби - iї мелодійні ходи не нові, це все ті ж секундові наспівки, з яких була зіткана головна тема першої частини, - i грон кластерів в партії фортепіано.

Б. Кац бачить структурно-інтонаційний зв'язок провідної мелодії другої частини зі знаменною мелодією. Побудова мелодійної лінії на основі обмеженої кількості коротких наспівок нагадує про твори російських майстрів допетровської епохи. Кожен розділ частин мелодії музикознавець називає рядками, тоді як мотиви можна було б назвати погласицями. Але сила самобутності та індивідуальності музичної мови Уствольської така, що це своєрідне втілення настільки злилося з індивідуальним стилем композиторки, що стало у неї єдиним авторським виразом [3].

Кожна наступна частина Композиції зменшується в об'ємі, і третя частина складає лише п'яту частину першої. Значення третьої частини набуває форму - післямови, вона звучить як відгомін тих драматичних подій, які розгорталися в першій частині. Вся частина звучить на $\boldsymbol{p}$ (в різних динамічних градаціях від $\boldsymbol{p}$ до $\boldsymbol{p p p p ) ~ щ о ~ в і д р а з у ~ в н о с и т ь ~}$ різкий контраст в загальне розгортання драматургії Композиції. Розосередження музичної тканини - протяжні співзвуччя у фортепіано та ненаголошені четвертні в партії туби (замість тридцять других, шістнадцятих та восьмих) - також сприяють створенню ефекту відстороненості. Боязке чергування терцій та квінт у фортепіано, глухий, низький, довгий звук у туби і мелодійні уривки у флейти перериває гуркотіння кластерів й вереск флейти, як нагадування про настрої першої частини. Але потім знову повертається умиротворенне звучання кількох звуків теми у флейти, відчужені інтервали фортепіано і відзвуки у туби. Третя частина - це своєрідний компроміс в зрівноважуванні неординарного інструментального складу твору, тому що саме тут звучання фортепіано, туби і флейти пікколо, збираючись в хорал, набуває достатню гармонійність.

Висновки. Авторське трактування тембрів інструментів в Композиції № 1 формується в контексті концентрованого композиторсько- 
го мислення Уствольської, що не допускає навіть думки не те що про зайві, але й просто про додаткові деталі. Така спрямованість визначає важливе значення особливостей тематизму, ритміки, будови вертикалі і динаміки в вибудовуванні образів інструментальної партитури.

У творчості Уствольської зростає значимість елементів, які раніше вважалися другорядними відносно темброутворення, таких як артикуляція, штрихи, динаміка. Наявність багатого нюансування дозволяє досягти великої кількості темброколористичних «градацій», створити свого роду «рельєф» всередині оркестрової тканини або іiі окремих пластів. Вона «обумовлює» інтонування майже кожного звуку», наділеного «експресією дисонансу і консонансу» (В. Холопова). Нерідко в творах відбувається дуже тонкий розподіл барв всередині однієї фрази: точно зважуються динамічні відтінки, нюанс окремих тонів. Застосовуються спеціальні знаки, що визначають характер інтонування - всілякі умовні символи для позначення видів звуковидобування та прийомів гри, в яких композиторка часом знаходить точний еквівалент образу. Нарешті, в ремарках нерідко враховується те, шо раніше було в рамках виконавської волі.

Трактування тембрів інструментів змінюється в процесі камернізації інструментальної творчості Уствольської. Скорочення інструментів, а отже і оркестрових голосів партитури призводить до згортання масштабів форми, до одночастинності. При цьому зростає, 3 одного боку, роль кожного інструмента в драматургії твору, а з іншого боку, зростає значущість композиторсько-виконавських прийомів.

Особливе значення в композиційній побудові «Dona nobis pacem» набуває тембр туби, в якому Г. Уствольській вдалося розгледіти потенціал сольно-мелодійного інструменту. Однак зауважимо, що в кількісному відношенні в творчості композиторки переважають твори, в яких туба проявляє себе, перш за все, як оркестрово-ансамблевий інструмент, як невід'ємний учасник мідної духової групи, як вірний васал, що підтримує свої тембром-профундо звучання всього оркестру.

Спрямованість Уствольської до крайнощів, неприйняття «середніх» станів, граничність експресії, полярне протиставлення динаміки, доведене до краю нюансування - всі ці ключові риси стилю композиторки пояснюють присутність партії туби в інструментальній тканині переважної більшості творів. Масивний суворий тембр цього інструмента найнижчий за регістром, стає крайнім полюсом партитури Уствольської, іiі опорою. Тетяна Чередниченко зазначила, що 
висотна шкала в фактурі творів Уствольської постає як система розташованих один над одним, спрямованих вгору плато. Внизу сильний басовий голос. Голос туби. «Його лінія подається в плакатному збільшенні завдяки широкому та густому тембру, що дає старт спрямованості композиторки до особистого абсолюту» [7].

\section{СПИСОК ЛІТЕРАТУРИ}

1. Гладкова О. Галина Уствольская. Музыка как наваждение. СПб.: Музыка, 1999. 168 с.

2. Гнатенко А. Искусство как ритуал: размышления о феномене Галины Уствольской. Музыкальная академия. Вып. 4. С. 24-32.

3. Кац Б. Семь взглядов на одно сочинение. Советская музыка . 1980. Вып. 2. С. 9-16.

4. Харитонов А. Звукоизвлечение на медных духовых инструментах как артикуляционно-штриховой феномен. М.: Водолей, 2010. 144 с.

5. Цытович В. О специфике тембрового мышления Белы Бартока : автореф. дис. ... канд. искусствоведения: спец. 17.00.03. Л., 1973. 23 с.

6. Цытович В. Фонизм оркестровой вертикали Дебюсси. Дебюсси и музыка ХХ века. Л.: Музыка, 1983. С. 64-90.

7. Чередниченко Т. Музыкальный запас. 70-е. Портреты. Случаи. М.: Новое литературное обозрение, 2002. 592 с.

\section{REFERENCES}

1. Gladkova, O. (1999) Galina Ustvolskaya. Music is like an obsession. St. Petersburg: Musica [in Russian].

2. Gnatenko, A. (1995) Art as a ritual: reflections on the phenomenon of Galina Ustvolskaya. Musicalnaya Academiya. Vip. 4. S. 24-32 [in Russian].

3. Katz, B. (1980) Seven views on one work. Sovetskaya musica. Vip. 2. S. 9-16 [in Russian].

4. Kharitonov, A. (2010) Sound extraction on brass instruments as an articulation-dashed phenomenon. M.: Vodolei [in Russian].

5. Tsytovich, V. (1973) About the specifics of timbre thinking of Bela Bartok: author's abstract. dis. for the competition uch. degree of cand. art studies: special. 17.00.03. L. [in Russian].

6. Tsytovich, V. Fonizm of the orchestral vertical Debussy. Debussy and music of the twentieth century. L.: Musica, 1983. S. 64-90 [in Russian].

7. Cherednichenko, T. (2002) Music stock. The 70th. Portraits. Cases. M.: Novoe Literatyrnoe Obozrenie, [in Russian].

Стаття надійшла до редакції 21.06.2017 